\title{
Description of a new species of Microglanis (Siluriformes: Pseudopimelodidae) from the Amazon basin, Amazonas State, Brazil
}

\author{
Lucas Ribeiro Jarduli ${ }^{1}$ and Oscar Akio Shibatta ${ }^{1,2}$
}

The first species of Microglanis from the rio Amazonas, Amazonas State, Brazil is described. This species differs from all congeners by the forked caudal fin, and color pattern of the supraoccipital region consisting of two elliptical and juxtaposed pale spots, besides a combination of morphometrics characters.

A primeira espécie de Microglanis da calha do rio Amazonas, estado do Amazonas, Brasil é descrita. Essa espécie difere de todas as congêneres pela nadadeira caudal bifurcada e padrão de colorido da região supraoccipital constituído por duas manchas elípticas claras e justapostas, além de uma combinação de caracteres morfométricos.

Key words: Bumble-bee catfish, Multivariate morphometrics, Systematics.

\section{Introduction}

Microglanis Eigenmann, 1912 is the most species-rich genus of Pseudopimelodidae, with 21 described species (Ottoni et al., 2010; Ruiz \& Shibatta, 2010), besides other possible new species (Shibatta, 2003). The genus was considered monophyletic by Shibatta (1998) and differs from other pseudopimelodids especially by the sharing of three characters: small size, rarely reaching $80 \mathrm{~mm}$ standard length; incomplete lateral line; and premaxillary tooth patch with rounded margin, without posterior projection (Schultz, 1944; Gomes, 1946; Mees, 1974, 1978). The species have a body color pattern consisting of orange-brown with large dark-brown spots, which justify their vernacular name: bumble-bee catfish.

Species of Microglanis are widely distributed in South America, from northern Venezuela to Uruguay, and also west of Andes (Shibatta, 2003). However, a more scrutinous evaluation on the distribution of these species reveals a large gap in the brazilian Amazon region, where no new species had been registered to date. Species of Microglanis described from the Amazon basin were so far restricted to the upper region, in Peru and Ecuador: Microglanis zonatus Eigenmann \& Allen, 1942, from río Morona, Peru and M. pellopterigius Mees, 1978, from río Araguarico, Ecuador. Microglanis poecilus Eigenmann, 1912 and M. secundus Mess, 1974 are also recorded to the Amazon basin (Mees, 1974; Shibatta, 2007), however they were originally described from coastal areas of the Guiana shield.
During the field expeditions for fish collection in rio Amazonas during the Calhamazon project between 1994 and 1996, first specimens of a new species of Microglanis were caught near the mouth of some major tributaries. Subsequent effort provided additional material and this species is herein described.

\section{Material and Methods}

Body measurements were taken point-to-point with a digital caliper with accuracy of $0.1 \mathrm{~mm}$. Twenty morphometric characters and counts were taken preferably on the left side of the fish, under stereomicroscope, according to Mori \& Shibatta (2006). Meristic data included counts of dorsal, pectoral, pelvic, anal and caudal-fin rays; gill rakers; serrations of pectoral-fin spine; and pores of lateral line of trunk. Counts of vertebrae, ribs, branchiostegal rays, proximal pterygiophores and procurrent caudal-fin rays, along with osteological observations, were made on one cleared and stained specimen prepared according to Dingerkus \& Uhler (1977). Vertebral counts included only free centra (anterior elements of complex centrum were not counted), and the compound caudal centra (preural $1+$ ural 1) counted as a single element.

Specimens of all other described species of Microglanis were examined for comparison with the new species, except M. ater Ahl, 1936, M. zonatus Eigenmann \& Allen, 1942 and M. minutus Ottoni, Mattos \& Barbosa, 2010. For those species

${ }^{1}$ Universidade Estadual de Londrina, Programa de Pós-Graduação em Ciências Biológicas, Departamento de Biologia Animal e Vegetal, Centro de Ciências Biológicas, 86057-970 Londrina, PR, Brazil. shibatta@uel.br(OAS) 
comparisons were through characters obtained from pictures and data available in the literature. The new species and congeners were compared by size-free canonical variate analysis with the program PAST (Hammer et al., 2001).

The examined material belongs to the following institutions: Academy of Natural Sciences of Drexel University, Philadelphia (ANSP); California Academy of Sciences, San Francisco (CAS); Instituto Nacional de Pesquisas da Amazônia, Manaus (INPA); Museu de Ciências e Tecnologia da Pontifícia Universidade Católica do Rio Grande do Sul, Porto Alegre (MCP); Museo de la Escuela Politécnica Nacional de Quito, Ecuador (MEPN); Museu Nacional de Historia Natural del Paraguay, San Lorenzo (MNHNP); Museu Nacional, Rio de Janeiro (MNRJ); Museu de Zoologia da Universidade Estadual de Londrina, Paraná (MZUEL); Museu de Zoologia da Universidade de São Paulo, São Paulo (MZUSP); Muséum d'histoire naturelle de la Ville de Genève, Geneva (MHNG); National Museum of Natural History, Smithsonian Institution, Washington, D.C. (USNM); and Royal Ontario Museum, Toronto (ROM).

\section{Results \\ Microglanis lundbergi new species Figs. 1-2}

Holotype. INPA 28577, 27.7 mm SL, Brazil, Amazonas, Tefé municipality, Alvarães, Costas das Capivaras, rio Solimões, $03^{\circ} 14.11^{\prime} \mathrm{S} 64^{\circ} 41.15^{\prime} \mathrm{W}, 13$ Jan 2001 , W. Crampton.

Paratypes. Brazil, Amazonas: INPA 18774, 3 (1 c\&s, $24.7 \mathrm{~mm}$ SL), 22.3-24.7 mm SL, collected with the holotype. MZUSP 112217 , 1, $23.3 \mathrm{~mm}$ SL, between Santa Maria and Itacoatiara, rio Amazonas, close to rio Madeira (7.6 km upstream), stretch between $3^{\circ} 21^{\prime} 26.0^{\prime \prime} \mathrm{S}$ $58^{\circ} 40^{\prime} 29.3$ "W and 3'21'24.1"S 58 39'36.2"W, 18 Oct 1994, Westneat et al. MZUSP 112218, 1, $23.1 \mathrm{~mm} \mathrm{SL}$, rio Amazonas, nearby tributary, rio Madeira (19.3 km downstream), Itacoatiara, stretch between $3^{\circ} 16^{\prime} 33.8^{\prime \prime S} 58^{\circ} 57^{\prime} 03.9^{\prime \prime} \mathrm{W}$ and 3 $3^{\circ} 16^{\prime} 46.7^{\prime \prime S}$ 5856'34.0'W, 5 Aug 1996, A. Zanata et al. MZUSP 112219, 2, 21.2-25.7 mm SL, rio Amazonas, nearby tributary, rio Madeira (17.6 km downstream), Nova Oriente, stretch between $3^{\circ} 16^{\prime} 35.6^{\prime \prime} \mathrm{S}$ $58^{\circ} 56^{\prime} 52.1^{\prime \prime} \mathrm{W}$ and $3^{\circ} 16^{\prime} 49.1^{\prime \prime S} 58^{\circ} 56^{\prime} 36.5^{\prime \prime} \mathrm{W}, 4$ Aug 1996, CoxFernandes et al. MZUSP 112220, 1, 24.5 mm SL, rio Amazonas, nearby tributary, rio Madeira (22.2 km downstream), Nova Oriente, stretch between $3^{\circ} 16^{\prime} 40.8^{\prime} \mathrm{S} 58^{\circ} 56^{\prime} 52.8^{\prime \prime} \mathrm{W}$ and $3^{\circ} 16^{\prime} 50.6^{\prime \prime S}$ 58 56'30.4'W, 4 Aug 1996, C. Cox-Fernandes et al. MZUSP 112221, 1, $20.8 \mathrm{~mm}$ SL, rio Amazonas, nearby tributary, rio Madeira, stretch between $3^{\circ} 16^{\prime} 34.3^{\prime \prime} \mathrm{S} 58^{\circ} 57^{\prime} 02.2^{\prime \prime} \mathrm{W}$ and $3^{\circ} 16^{\prime} 45.2^{\prime \prime} \mathrm{S} 58^{\circ} 56^{\prime} 39.8^{\prime \prime} \mathrm{W}$, 5 Aug 1996, M. Toledo-Piza et al.

Diagnosis. Microglanis lundbergi is distinguished from all congeners by the presence of a forked caudal fin with a deep notch between upper and lower lobes (vs. rounded, emarginated, or slightly forked), two pale juxtaposed and elliptical spots in the supraoccipital region (vs. wide, or narrow, or absent supraoccipital pale band), and shorter length of the adipose-fin base (13.1-16.6\% of SL; except for M. carlae 14.7$19.1 \%$, M. secundus $12.2-18.2 \%$ and $M$. iheringi $14.7-19.0 \%$ ).
It also differs from other species on the following morphometric characters: length of the head $27.4-30.0 \%$ of SL ( vs. $24.7-26.4 \%$ in $M$. carlae; $23.9-25.1 \%$ in $M$. iheringi; $23.0-26.1 \%$ in $M$. parahybae; $23.0-25.4 \%$ in $M$. pataxo; $23.5-26.3 \%$ in $M$. robustus); eye diameter $8.0-9.9 \%$ of HL (vs. $12.4-17.6 \%$ in $M$. variegatus); interorbital distance $40.4-44.2 \%$ of HL (vs. 45.9$51.5 \%$ in M. cottoides; $46.5-49.8 \%$ in M. leptostriatus; 46.6 $48.6 \%$ in M. malabarbai; $38.1-39.1 \%$ in M. pellopterygius; $50.9-53.1 \%$ in $M$. poecilus); mouth width $38.0-47.3 \%$ of HL (vs. $19.0-25.8 \%$ in M. cibelae; $17.5-21.9 \%$ in M. garavelloi; 20.1-22.6\% in M. nigripinnis); predorsal length 35.5-38.6\% of SL (vs. 38.9-46.2\% in M. eurystoma); lateral line pores 6-8 (vs. 9 in M. ater and M. secundus); principal caudal rays 15 (vs. 14 in M. zonatus).

Description. Morphometric data are summarized in Table 1. Small size (up to $27.7 \mathrm{~mm} \mathrm{SL}$ ), head and anterior part of trunk depressed, laterally compressed from dorsal fin to caudal peduncle. Greatest body depth at dorsal-fin origin, greatest body width at pectoral-fin base.

Head slightly depressed, anteriorly rounded in dorsal view. Eye small, closer to mouth than to distal margin of operculum, more dorsal than lateral, inserted after first third of head length, completely covered by skin without free orbital margin. Snout short. Anterior nostril tubular, closer to upper lip than to eye; posterior nostril near anterior margin of eye, with anterior membrane. Gill membrane free from isthmus; nine branchiostegal rays. Gill rakers spiniform, usually small; first branchial arch with 1, 1, 4 gill rakers.

Mouth wide, terminal. Premaxillary tooth patch with rounded margin, no posterior projection. Dentary tooth patch semicircular, larger and wider than premaxillary patch. Tooth villiform, curved backwards.

All barbels thin, flattened in cross section. One maxillary pair, two mental pairs. Outer mental barbel surpassing pectoral-fin spine base; inner mental barbel shorter, reaching almost half length of outer mental barbel. Maxillary barbel short, not reaching pectoral-fin base. Dorsal fin I,6, located anteriorly to half of body length, posterior margin rounded; spinelet present. Dorsal-fin spine straight, shorter than branched rays.

Adipose fin relatively small. Caudal fin forked with deep notch, lower lobe slightly longer than upper lobe. Principal caudal rays 15 , dorsal procurrent rays 15 , ventral procurrent rays 10. Anal fin short and rounded, iv,7. Pectoral fin I,5. Pectoral spine strong, slightly flattened, with developed serrations on both margins, completely covered by thin skin. Anterior margin of pectoral spine with 10-14 hooks; hooks on distal portion antrorse or straight. Posterior margin of pectoral spine with 7-9 retrorse serrations greater than anterior margin, increasing in size from proximal to distal portion (Fig. 2). Tip of pectoral spine ossified, very strong and sharp. Pelvic fin rounded, with i,5 rays. Vertebrae 27. Ribs 6.

Posterior cleithral process short, narrow and pointed, spiniform. Proximal pterygiophores 9. Swim bladder relatively 
large, filling almost entire abdominal cavity (length $21.5 \%$ of SL, width $13.0 \%$ of SL), cordiform, with simple T-shaped septum. Trunk lateral line with 6-8 pores, not surpassing vertical through end of dorsal-fin base.
Color in alcohol. Ground color orange-brown. Head darkbrown with two elliptical and juxtaposed pale spots in supraoccipital region, confluent or not with a pale band in post-opercular region, reaching pectoral-fin base. Two small,

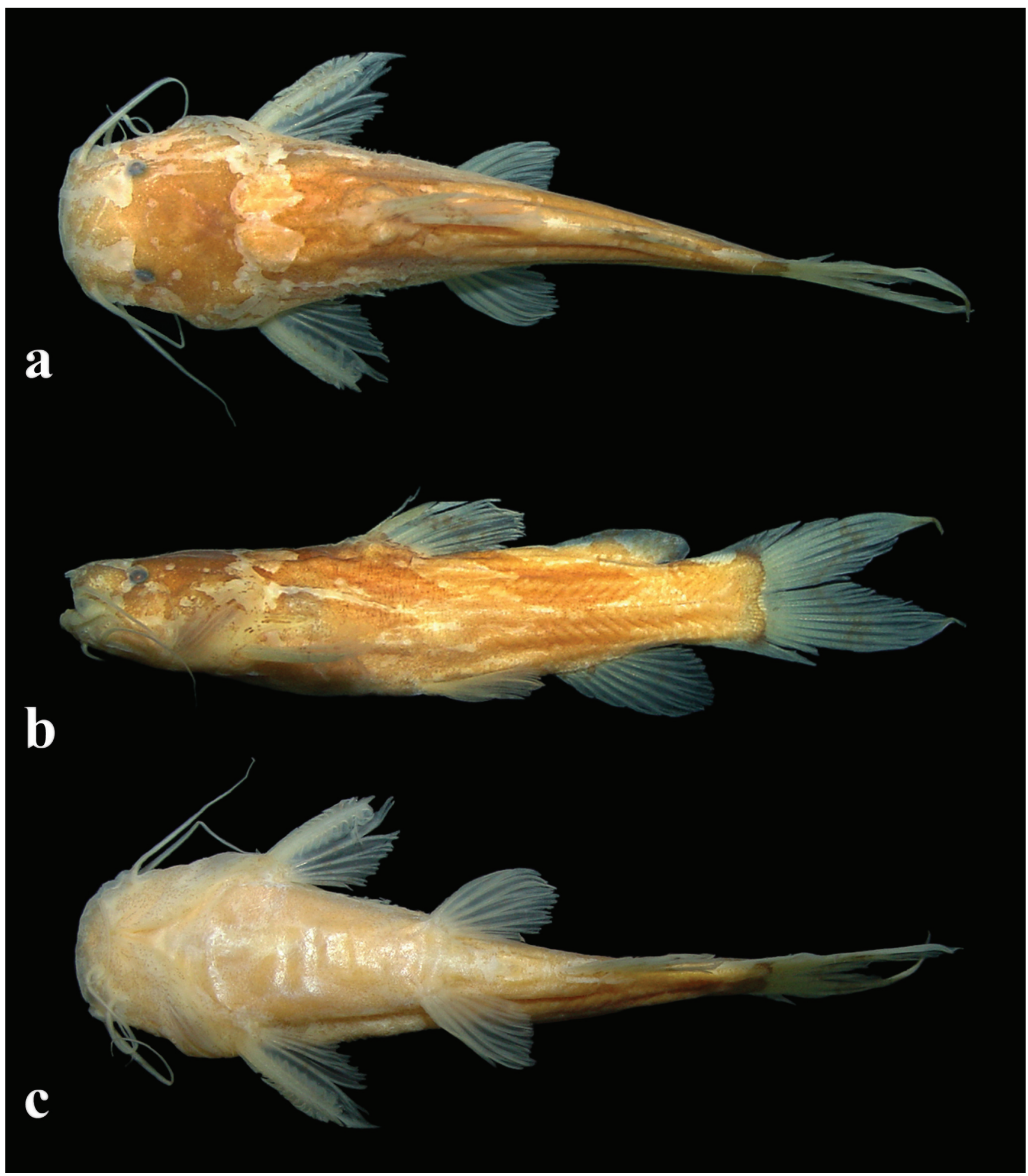

Fig. 1. Dorsal (a), lateral (b) and ventral (c) view of Microglanis lundbergi, INPA 28577, holotype, $27.7 \mathrm{~mm}$ SL, rio Solimões, Tefé, Costa das Capivaras, Amazonas, Brazil. 
Table 1. Morphometric data of Microglanis lundbergi $(\mathrm{n}=9)$. $\mathrm{SD}=$ standard deviation. Minimum (Min.) and Maximum (Max.) values include holotype and paratypes.

\begin{tabular}{lrcc}
\hline Characters & Holotype & Min.-Max. & Mean \pm SD \\
\hline Standard length (mm) & 27.7 & $20.8-27.7$ & $23.7 \pm 2.2$ \\
& Percents of SL & & \\
Head length & 29.7 & $27.4-30.0$ & $28.4 \pm 1.1$ \\
Pelvic fin length & 19.3 & $15.8-20.1$ & $18.0 \pm 1.3$ \\
Dorsal spine length & 15.9 & $11.4-15.9$ & $13.0 \pm 1.4$ \\
Pectoral spine length & 19.2 & $15.5-19.2$ & $16.9 \pm 1.2$ \\
Posterior cleithral process length & 11.9 & $9.6-14.5$ & $11.8 \pm 1.7$ \\
Predorsal length & 38.6 & $35.5-38.6$ & $37.1 \pm 1.1$ \\
Preventral length & 54.4 & $49.5-54.4$ & $52.1 \pm 1.7$ \\
Preanal distance & 72.5 & $68.1-74.1$ & $70.9 \pm 2.1$ \\
Caudal peduncle depth & 11.2 & $9.9-11.3$ & $10.8 \pm 0.4$ \\
Caudal peduncle length & 12.2 & $9.9-17.7$ & $14.4 \pm 3.0$ \\
Body width & 30.4 & $26.4-30.4$ & $27.6 \pm 1.4$ \\
Dorsal-fin base length & 13.5 & $9.7-14.4$ & $13.0 \pm 1.4$ \\
Adipose-fin base length & 16.6 & $13.1-16.6$ & $14.6 \pm 1.1$ \\
Anal-fin base length & 12.2 & $9.5-12.9$ & $11.0 \pm 1.0$ \\
& & \\
Interorbital length & Percents of HL & & \\
Eye diameter & 44.2 & $40.4-44.2$ & $42.0 \pm 1.3$ \\
Snout length & 9.8 & $8.0-9.8$ & $9.1 \pm 0.7$ \\
Mouth width & 43.8 & $38.3-43.8$ & $40.8 \pm 2.1$ \\
Maxillary barbel length & 44.4 & $38.0-47.3$ & $43.4 \pm 2.4$ \\
\hline
\end{tabular}

semilunar, pale stripes in anterior region of head in dorsal view, between edge of snout and anterior orbital margin. Barbels pale, scattered by dark-brown chromatophores.

Ventral region light-brown. Trunk with large dark-brown blotch, saddle shaped, horizontally divided by pale lateral line. Caudal region with two dark-brown blotches of irregular shape. First one at dorsolateral position, beginning below anterior portion of adipose fin, extending up to half of caudal length. Second one at caudal peduncle, as dark brown spot approximately rectangular with irregular margins.

Pectoral and pelvic fins with scattered dark chromatophores. Dorsal fin with dark band covering distal half, with hyaline margin on all rays. Adipose fin with dark spot on anterior portion, confluent to caudal dark-brown blotch. Anal fin with thin dark band approximately median. Caudal fin with thin vertical "3-shaped"dark band.

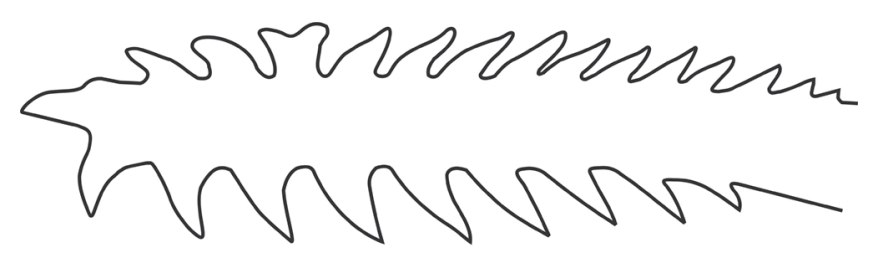

Fig. 2. Dorsal view of left pectoral spine of Microglanis lundbergi INPA 28577, $27.7 \mathrm{~mm}$ SL, holotype, rio Solimões, Tefé, Costa das Capivaras, Amazonas, Brazil. Scale bar $=1 \mathrm{~mm}$.
Distribution. Microglanis lundbergi is known from rio Amazonas, near the Madeira and Itacoatiara tributaries, and from rio Solimões, in Tefé, Amazonas, Brazil (Fig. 3).

Habitat notes. The individuals were collected in the main channel of the rio Amazonas (white waters), bottom rich in organic matter and pieces of wood (data obtained from lots' labels).

Etymology. The specific name is homage to the North American ichthyologist John G. Lundberg, coordinator of the Calhamazon project, who kindly provided specimens of the new species, and for his great contribution to the Systematics of Neotropical catfishes.

\section{Discussion}

All the characters proposed by Shibatta (1998), supporting the monophyly of Microglanis, are present in M. lundbergi. The morphological characters that sustain the hypothesis that the species is new are discussed as follows.

In Microglanis, a forked caudal fin with pointed lobes is a unique condition only found in M. lundbergi. Microglanis iheringi Gomes, 1946, from río Turmero, Venezuela, is the only congener whose caudal-fin shape - slightly forked with caudal lobes with the same size - roughly resembles the condition present in M. lundbergi, which may differ by a deeper notch in the caudal fin. Among the remaining species of Microglanis the most generalized caudal-fin shape is the emarginated, found in several species such as M. carlae from río Salado, río Paraguay basin, M. cibelae from coastal basins of Santa Catarina and Rio Grande do Sul, and M. garavelloi from the upper rio Paraná. Less frequently forms are: bilobed caudal fin, present in M. nigripinnis from coastal basins of the Rio de Janeiro State and $M$. secundus from coastal regions of Guiana Shield; and rounded, as in $M$. zonatus from río Morona, Peru. Among other Pseudopimelodidae

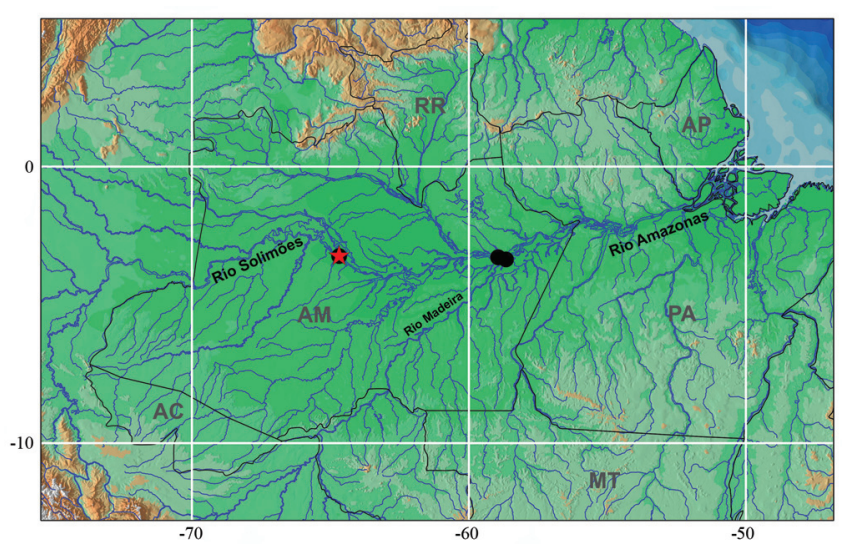

Fig. 3. Map of distribution (black dots) of Microglanis lundbergi. Red star $=$ type locality. Brazilian states acronym: $\mathrm{AC}=\mathrm{Acre} ; \mathrm{AM}=$ Amazonas; $\mathrm{AP}=$ Amapá $\mathrm{MT}=$ Mato Grosso; $\mathrm{PA}=$ Pará; $\mathrm{RR}=$ Roraima . 
only Pseudopimelodus pulcher has a forked caudal fin, which is certainly a case of convergence or secondary reversion in the evolutionary history of the family due to frequent occurrence of non-forked caudal fins in the group.

Another peculiar characteristic of $M$. lundbergi is the presence of two elliptical light spots in the supraoccipital region, distinguishing it from the other species that in general present a pale band in this region, which can be narrow, like in M. leptostriatus from the middle rio São Francisco, wide in M. cottoides from drainages of Laguna dos Patos and the río Uruguay basin, and M. parahybae from the rio Paraíba do Sul basin, or cordiform in M. robustus from the lower rio Tocantins basin.

Among all species of the genus, the coloration pattern of $M$. lundbergi is similar to species of the $M$. cottoides complex, whose members are distributed on southern and southeastern Brazil. This complex includes M. cibelae, M. cottoides, M. malabarbai, and $M$. nigripinnis, which are grouped by the following combination of characters: long subdorsal dark band, reaching the pectoral fin, with a clear spot located below the dorsal spine; caudal lobes practically of the same size; dark blotch on adipose fin; and dark stripe of caudal fin roughly number three shaped. However, the results of the canonical variables evidenced that M. lundbergi has morphometric differences from the species of M. cottoides complex, and it is morphologically more similar to the Amazonian M. poecilus (Fig. 4). The species of M. cottoides complex were morphologically distinct from other species of northern Brazil by the first and second axes (Table 2), whose morphological variables with greater weights were the length of the head, interorbital distance, mouth width, dorsal-spine length, and adipose-fin base length. Regarding the delimitation of groups based on similarities of morphology and coloration among the species of Microglanis, Mori \& Shibatta (2006) and Alcaraz et

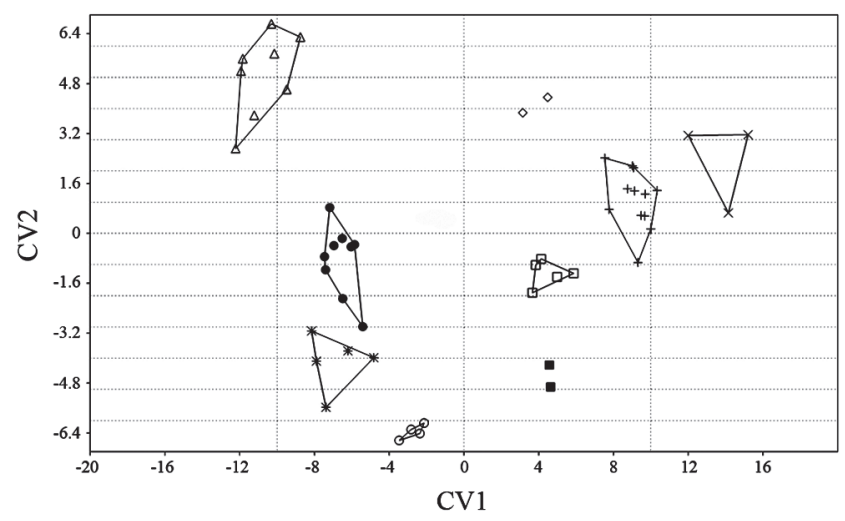

Fig. 4. Scatter diagram of nine species of Microglanis on first and second axis of size-free Canonical Variates Analysis: (circle) Microglanis iheringi $(\mathrm{n}=4)$; (diamond) $M$. pellopterygius $(\mathrm{n}=2)$; (asterisk) M. poecilus $(\mathrm{n}=5)$; (triangle) $M$. secundus $(\mathrm{n}=8)$; (plus) $M$. cibelae $(\mathrm{n}=12)$; (square) $M$. cottoides $(\mathrm{n}=5)$; (black square) M. malabarbai $(\mathrm{n}=2) ;(\mathrm{X})$ M. nigripinnis $(\mathrm{n}=3)$; (black circle) M. lundbergi $(\mathrm{n}=8)$.
Table 2. Weight of the variables in the first and second axes of size free canonical variate analysis (CV1 and CV2), of combined samples of the species Microglanis cibelae, $M$. cottoides, M. iheringi, M. lundbergi, M. malabarbai, M. nigripinnis, M. pellopterygius, M. poecilus and M. secundus.

\begin{tabular}{lcc}
\hline & CV1 (81.11\%) & CV2 (16.47\%) \\
\hline Head length & -0.14042 & -0.1891 \\
Interorbital distance & 0.10768 & 0.43904 \\
Eye diameter & -0.11396 & -0.19571 \\
Snout length & -0.014809 & 0.41971 \\
Mouth width & 0.10935 & 0.07983 \\
Maxillary barbel length & 0.023589 & 0.26127 \\
Anal fin length & -0.072884 & 0.050899 \\
Dorsal spine length & -0.069149 & 0.13113 \\
Pectoral spine length & 0.10587 & 0.31419 \\
Humeral process length & -0.037374 & 0.0036545 \\
Predorsal distance & -0.11807 & 0.060669 \\
Preventral distance & -0.088499 & -0.073199 \\
Preanal distance & 0.34928 & -0.38767 \\
Caudal peduncle height & -0.084459 & -0.26858 \\
Caudal peduncle length & -0.059994 & 0.10492 \\
Body width & -0.073092 & -0.2741 \\
Dorsal-fin base length & -0.061181 & 0.023965 \\
Adipose-fin base length & -0.061677 & 0.10203 \\
Anal-fin base length & -0.011569 & -0.18645 \\
\hline
\end{tabular}

al. (2008) suggest that they are merely artificial, and call attention to the need of further phylogenetic analysis encompassing all species to determine natural lineages within the genus.

Comparative material. Microglanis carlae. Paraguay. MHNHP 3667, holotype, $34.1 \mathrm{~mm} \mathrm{SL}$, río Salado, río Paraguay basin, 26³9'S 5805'W; MZUSP 98255, paratypes, 5, 23.4-29.1 mm SL. Microglanis cibelae: Brazil. Rio Grande do Sul. MCP 19822, paratypes, 3, 34.9-48.7 mm SL, arroio do Ouro, tributary of rio Maquiné, 29³4'00"S 50¹6'00"W; MCP 21190, 9, 24.6-42.4 mm SL, Osório, rio Tramandaí basin, 2957'57'S 50¹3'45"W. Microglanis cottoides: Brazil. Rio Grande do Sul. MCP 10826, 5, 38.2-49.5 mm SL, rio Sanga das Águas Frias, rio Uruguai basin; MCP 17706, 4, 25.1-45.3 mm SL, arroio Quarizinho, tributary of

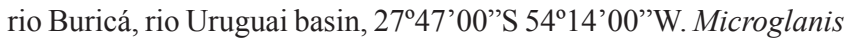
eurystoma. Brazil. Santa Catarina. MCP 13405, holotype, 77.6 $\mathrm{mm}$ SL, rio Uruguai, $27^{\circ} 18^{\prime} 00^{\prime} \mathrm{S} 52^{\circ} 20^{\prime} 00^{\prime \prime} \mathrm{W}$, Rio Grande do Sul; MCP 12698, paratypes, 10, 26.3-41.1 mm SL, arroio do Passo

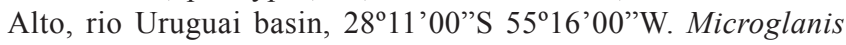
garavelloi. Brazil. Paraná. MZUSP 88006, holotype, 31.7 mm SL ribeirão Taquari, upper rio Paraná basin; MZUSP 1732, paratypes, 2, 23.7-30.8 mm SL, ribeirão Taquari, 2312'24"S 5056'50'W; MCP 1678, paratypes, 4 (3 c\&s), 24.6-27.9 mm SL, ribeirão Taquari. Microglanis iheringi. Venezuela. Aragua. USNM 121985, paratype, 1, 31.3 mm SL, río Turmero. Portuguesa. CAS 64403, 3, 27.4-41.0 $\mathrm{mm}$ SL, río Orinoco. Microglanis leptostriatus. Brazil. Minas Gerais. MZUSP 47456, paratypes, 2, 28.4-28.7 mm SL, rio Verde, rio São Francisco basin; MZUEL 3733, paratypes, 6, 19.3-27.4 mm SL, rio Cruz, rio São Francisco basin. Microglanis malabarbai. Brazil. Rio Grande do Sul. MCP 37252, 1, 47.7 mm SL, arroio Alexandrino, rio Ijuí basin, 2810'25”S 5448'05"W; MCP 37187, 1, $50.1 \mathrm{~mm}$

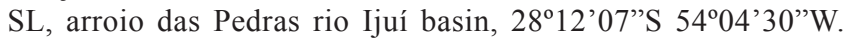
Microglanis nigripinnis: Brazil. Rio de Janeiro. MZUSP 80223, 1, $47.2 \mathrm{~mm} \mathrm{SL}$, tributary of rio São João, Eastern basin; MZUSP 80229, 2, 38.3-43.5 mm SL, tributary of rio São João. Microglanis 
parahybae. Brazil. Rio de Janeiro. MNRJ 15989, 5, 30.3-34.2 mm SL, rio Dois Rios, rio Paraíba do Sul basin; MNRJ 16047, 5, 28.6$38.9 \mathrm{~mm}$ SL, rio Muriaé, rio Paraíba do Sul basin. Microglanis pataxo. Brazil. Bahia. MZUSP 54516, 10, 24.9-31.4 mm SL, rio Mucuri, East coast basin. Microglanis pellopterygius: Ecuador. Napo. ANSP 130437, holotype, $68.1 \mathrm{~mm} \mathrm{SL}$, río Aguarico, $00^{\circ} 06^{\prime} \mathrm{N}$ $76^{\circ} 51^{\prime} \mathrm{W}$; MEPN 88.4-12, 2, 22.4-23.1 mm SL, tributary of the río Aguarico. Microglanis poecilus. Guiana. Kurupukari. ROM 60738, 1, $22.5 \mathrm{~mm}$ SL, unknown stream from río Essequibo, 446'20"S 58 45'; ROM 62390, 1, $17.1 \mathrm{~mm}$ SL, Shimiri Stream, Yawiri, río Essequibo basin, 442'13"S 5842'43'W; ROM 62391, 1, 17,1 mm SL, río Essequibo, 448'22'S 5846'14"W. Microglanis poecilus. Brazil. Amazonas. INPA 28575, 3, 18.6-20.6 mm SL, rio Aripuanã, rio Madeira basin. Roraima. INPA 28576, 3, 19.8-20.4 mm SL, igarapé Ano Bom, rio Branco basin; INPA 8052, 3, 24.8-26.2 mm SL, igarapé Maracá, rio Branco basin. Pará. INPA 6828, 3, 19.2$25.8 \mathrm{~mm}$ SL, rio Jamanxin, rio Tapajós basin, 527' $11^{\prime \prime S} 55^{\circ} 52^{\prime} 40^{\prime \prime} \mathrm{W}$. Microglanis robustus. Brazil. Pará. INPA 8053, holotype, 20.3 $\mathrm{mm}$ SL, lower rio Tocantins, rio Tocantins-Araguaia basin; INPA 32885, paratypes, 11 (2 c\&s), 18.4-23.3 mm SL, same data as holotype; INPA 7943, paratypes, 2, 20.0-22.2 mm SL; INPA 7957 , paratypes, 3, 19.2-21.7 mm SL, Jatobal, lower rio Tocantins. Microglanis secundus. Suriname. Brokopondo. MHNG 2621.038, 6, 18.9-27.1 mm SL, rio Mindrineti. Brazil. Pará. INPA 5730, 7 , 18.5-31.1 mm SL, rio Trombetas, rio Amazonas basin; INPA 7950, 3 (2 c\&s), 24.4-28.1 mm SL rio Trombetas, rio Amazonas basin. Microglanis variegatus. Ecuador. Vinces. USNM 083653, paratype, 1, $29.1 \mathrm{~mm}$ SL, pools in forests near Vinces. Los rios. MHNG 298.033, 2, 25.2-27.7 mm SL, río Palengue; MHNG 1232.11, 2 , 23.6-26.2 mm SL, Hazienda Clementina.

\section{Acknowledgments}

We are grateful to J. G. Lundberg, coordinator of the Calhamazon project, who provided specimens of the new species. We also thank O. Oyakawa (MZUSP), S. Fisch-Muller (MHNG), S. L. Jewett (USNM), C. Ferraris Jr. (CAS), Z. M. Lucena, C. Lucena (MCP), P. A. Buckup, M. Britto (MNRJ), J. Zuanon, L. R. Py-Daniel, M. Rocha (INPA), and R. Barriga (MEPN) for loans and/or permissions to access the material. To W. Crampton for useful informations. We thank M. Britto (MNRJ) and F. C. Jerep for pertinent suggestions on the manuscript. To Programa de Pós-Graduação em Ciências Biológicas da UEL and Coordenação de Aperfeiçoamento de Pessoal de Nível Superior (Capes), for partial financial support. To $\mathrm{CNPq}$ for providing research Grant to OAS (Proc. $n^{\circ} 308624 / 2009-2$ ).

\section{Literature Cited}

Alcaraz, H. S. V., W. J. Graça \& O. A. Shibatta. 2008. Microglanis carlae, a new species of bumblebee catfish (Siluriformes: Pseudopimelodidae) from the río Paraguay basin in Paraguay. Neotropical Ichthyology, 6: 425-432.
Dingerkus, G. \& L. Uhler. 1977. Differential staining of bone and cartilage in cleared and stained fish using alcian blue to stain cartilage and enzyme for clearing fish. Stain Technology, 52: 229-232.

Gomes, A. L. 1946. A review of Microglanis, a genus of South American Catfishes, with notes of related genera. Occasional Papers of the Museum of Zoology, 494: 1-19.

Hammer, Ø., D. A. T. Harper \& P. D. Ryan. 2001. PAST: Palaeontological Statistics Software Package for education and data analysis. Palaeontologia Electronica, 4: 1-9.

Mees, G. F. 1974. The Auchenipteridae and Pimelodidae of Suriname (Pisces, Nematognathi). Zoologische Verhandelingen, 132: 1246.

Mees, G. F. 1978. Two new species of Pimelodidae from northwestern South America (Pisces, Nematognathi). Zoologische Mededelingen, 23:253-261.

Mori, H. \& O. A. Shibatta. 2006. A new species of Microglanis Eigenmann, 1912 (Siluriformes: Pseudopimelodidae) from rio São Francisco basin, Brazil. Zootaxa, 3: 579-585.

Ottoni, F. P., J. L. O. Mattos \& M. A. Barbosa. 2010. Description of a new species of Microglanis from de rio Barra Seca basin, southeastern Brazil (Teleostei: Siluriformes: Pseudopimelodidae). Vertebrate Zoology, 60: 187-192.

Ruiz, W. B. G \& O. A. Shibatta. 2010. A new species of Microglanis (Siluriformes: Pseudopimelodidae) from lower Rio Tocantins basin, Pará, Brazil, with a description of superficial neuromasts and pores of lateral line system. Zootaxa, 2632: 53-66.

Schultz, L. P. 1944. The catfishes of Venezuela, with descriptions of thirty-eight new forms. Proceedings of the United States National Museum, 94: 173-338.

Shibatta, O. A. 1998. Sistemática e evolução da família Pseudopimelodidae (Ostariophysi, Siluriformes), com a revisão taxonômica do gênero Pseudopimelodus. Unpublished Ph.D. Dissertation, Universidade Federal de São Carlos, São Carlos, $357 \mathrm{p}$.

Shibatta, O. A. 2003. Family Pseudopimelodidae (Bumblebee catfishes, dwarf marbled catfishes). Pp. 401-405. In: Reis, R. E., S. O. Kullander \& C. J. Ferraris Jr. (Eds.). Check List of the Freshwater Fishes of South and Central America. Edipucrs, Porto Alegre.

Shibatta, O. A. 2007. Família Pseudopimelodidae. Pp. 103-104. In: Buckup, P. A., N. A. Menezes \& M. S. Ghazzi (Eds.). Catálogo das espécies de peixes de água doce do Brasil. Museu Nacional, Rio de Janeiro.

Submitted May 10, 2013 Accepted June 21, 2013 by Francisco Langeani Published September 30, 2013 